\title{
The role of the civil service in the industrialization of Nigeria
}

\section{Chiemeka Onyema}

Imo State University. Owerri. Nigeria. Email: emekaonyema4@gmail.com.

\begin{abstract}
The goal of berthing Nigeria's full-scale industrial revolution is yet to be achieved. All the industrial development plans have so far failed to accelerate the nation's industrialization, hence the country's low industrial base which has kept her in the league of developing nations. In fact, Nigeria has in recent times been experiencing deindustrialization, as several industries have collapsed and some others, such as Unilever and Michelin, have relocated to other countries. Several factors are responsible for Nigeria's low industrial development and they include: inadequate infrastructure (particularly, energy), poor technological base, multiple taxes and levies, and, the shortage and high cost of foreign exchange. Despite a growing body of literature on industrialization in Nigeria, not much has been written about the link between Public Service Reforms and industrialization in Nigeria. This paper examines the link between the implementation of Service Compact (Servicom) Charter and the achievement of Nigeria's industrial development policies, especially the 'Ease of Doing Business' Policy. The paper makes the case that the goal of industrializing Nigeria will not be possible without an efficient Public Service. Furthermore, the paper highlights the need for Nigerian public servants to have the right work attitude, and to be morally upright and patriotic, in order to create a business-friendly environment and to build investor confidence, so as to facilitate and accelerate the country's industrialization and overall national development. The author recommends that the Nigerian government should strengthen the implementation of the Servicom charter and also incorporate the charter into the industrialization plan.
\end{abstract}

Keywords: Industrialization; Deindustrialization; Service compact; Public service; National development.

Resumo. O papel do serviço civil na industrialização da Nigéria. O objetivo de alavancar a revolução industrial em grande escala da Nigéria ainda está por ser alcançado. Todos os planos de desenvolvimento industrial até agora não conseguiram acelerar a industrialização do país, daí a sua baixa base industrial, que a manteve na liga dos países em desenvolvimento. De fato, a Nigéria tem experimentado recentemente a desindustrialização, já que várias indústrias entraram em colapso e outras, como Unilever e Michelin, foram realocadas para outros países. Vários fatores são responsáveis pelo baixo desenvolvimento industrial
Received:

November 14, 2018

Accepted:

December 28, 2018

Released:

December 31, 2018

Full Text Article

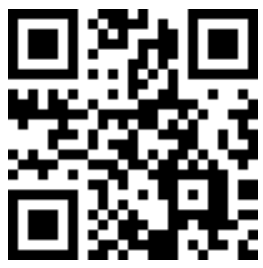

ORCID

(ㄷ) 0000-0002-4147-8751

Chiemeka Onyema 
da Nigéria e incluem infraestrutura inadequada (particularmente a energia), baixa base tecnológica, múltiplos impostos e taxas, bem como a escassez e alto custo do câmbio. Apesar de um crescente corpo de literatura sobre a industrialização na Nigéria, pouco se escreveu sobre a ligação entre as reformas dos serviços públicos e a industrialização na Nigéria. Este documento examina a ligação entre a implementação da Carta do Serviço Compacto (Servicom) e a realização das políticas de desenvolvimento industrial da Nigéria, especialmente a política de "Facilidade de Fazer Negócios". O artigo argumenta que o objetivo de industrializar a Nigéria não será possível sem um eficiente serviço público. Além disso, o artigo destaca a necessidade dos servidores públicos nigerianos terem a atitude correta de trabalho e serem moralmente íntegros e patrióticos, a fim de criar um ambiente favorável aos negócios e construir a confiança dos investidores, de modo a facilitar e acelerar a industrialização do país e o desenvolvimento nacional geral. 0 autor recomenda que o governo nigeriano fortaleça a implementação da carta de serviços e também incorpore a carta ao plano de industrialização.

Palavras-chave: Industrialização; Desindustrialização; Serviço compacto; Serviço público; Desenvolvimento nacional.

\section{Introduction}

Industrialization has been a
major feature of the economic development strategies of many nations since the industrial revolution in the eighteenth century. The term 'industrialization' refers to a process by which a nation's economy is transformed from an agrarian to an industrial economy. Industrialization describes the sustained economic growth following the application of inanimate sources of power to mechanize production (Abercromie et al., 2000). Technically, industrialization or industrializing denotes the transition in methods of production and raising productivity metamorphosing into industrial and technical enterprises on a large scale. The characteristics of industrialization include cultural rationalization; a division of labour; a factory system and mechanization; bureaucracy and administration by rules (Marshall, 1998).

The state of a nation's economy could be measured by its level of industrialization. This implies that the level of industrialization is a key indicator of economic development which is often discussed in terms of the phase or stage of industrialization - the stage could range from early to late, advanced to mature industrialization. A good number of African countries such as Nigeria, Kenya, Botswana, Zambia, to mention a few, are still at the early stages of industrialization characterized by lowcost and low-wage production using lowlevel foreign technology. Whereas advanced countries such as the United States of America, China, Canada, Russia and South Korea are experiencing their fourth industrial revolution and leading the match toward the fifth, their African counterparts appear to be struggling to advance beyond their first revolution.

Industrialization is most often discussed in terms of the utilization of technology in the sectors of the economy, demarcated into primary, secondary and tertiary sector. The primary sector comprises economic activities such as agriculture, horticulture, quarrying, and mining. This sector could be narrowed to the extraction of natural resources such as crude oil, natural gas, and solid minerals. The secondary sector of an 
economy is that part that caters for the manufacture of goods from the raw materials supplied by the primary sector industries (Abercromie et al., 2000). The manufacturing and construction industries dominate this sector. The tertiary sector is concerned with the provision of services usually delivered through financial services, education and health care service, transportation and communication industries, and the leisure industry. The provision of regulatory services could be viewed as a tertiary sector activity, thus the civil service could be placed here.

There are usually two main pathways to industrialization available to countries namely, import-substitution industrialization and export-led industrialization. Import-Substitution Industrialization (ISI) entails producing goods domestically instead of importing them. It is believed that ISI stimulates the growth of industries, creates employment opportunities, helps to redistribute income, leads to the acquisition of essential skills and technology, and promotes infrastructure development. Governments attempt to achieve ISI by implementing protective measures in form of outright bans on imports of certain items, import duties, quotas and industrial licensing to protect local industries (Ekeh, 2009). ISI pathway encourages labour-intensive production, thus, it is suitable for countries with large population (surplus labour) such as Turkey, Indonesia and Nigeria. It promotes the growth of cottage, small and medium scale industries.

Export-Led Industrialization (ELI) sometimes called export-oriented industrialization (EOI) or export substitution industrialization (ESI), is an economic policy designed to speed up the industrialization process of a country through exporting goods for which the nation has a comparative advantage. Governments seek to achieve this industrialization strategy through measures such as cutting export tariffs, granting export tax exemptions and export credits, establishing exportprocessing zones and trade liberalization. The benefits of export-led industrialization include increased foreign direct investment and the acquisition of foreign technologies. The economic successes of the East Asia Tigers-South Korea, Taiwan, Hong and Singapore in the 1980s are usually cited as instances of the potency of export-led industrialization (Johnston, 2016). In all, the choice of industrialization strategy or pathway is usually influenced by factors such as population size, natural resource endowment, development levels and per capita incomes. Other factors to take into consideration include infrastructure development priorities, potential for mobilizing external technology, availability of financial resources and, information and technical support (Ekeh, 2009).

\section{Industrialization of Nigeria}

Nigeria is still regarded as an underdeveloped nation in spite of her abundant mineral resources such as crude oil, natural gas, and a large human population. One then wonders why the country is still underdeveloped despite the availability of vital endowments. The readily cited impediments to Nigeria's development are the lack of visionary leadership and the high rate of public corruption in the management of national resources. No doubt, these reasons are very germane. However, the major impediment to Nigeria's development is the slow pace of the country's industrialization due to a weak industrial sector; an industrial sector incapable of harnessing raw materials and transforming them into finished products that meet global standard. This is compounded by the inability to develop and leverage indigenous technology in the industrialization process.

The Nigerian government and people made appreciable efforts to lay an 
industrial foundation in the early postindependence period through the mechanization of agriculture and the processing of agricultural products such as cocoa, groundnut, and palm oil, for local and export markets. Nigeria became a major exporter of cocoa, groundnut and palm oil. Unfortunately, these products were exported in their raw or semifinished forms, instead of transforming them into finished end-user products such as chocolate bars, refined nuts, groundnut oil, margarine, etc. For that reason, very few high level industries were developed around these products. The country therefore lost the golden opportunity to expand her industrial base in order to consolidate her industrialization.

The discovery of oil in 1956 at Oloibiri in the Niger Delta Region of Nigeria was a major factor in the country's early industrialization policy. However, the oil industry (downstream, midstream and upstream) was (and still is) dominated by foreign multinationals such as Shell D'Arcy (now, Shell-BP Petroleum Development Company of Nigeria Limited), Mobil Oil Corporation, Elf, Safrap (now, Agip Oil Company) (NNPC, 2016). The reliance on multinationals and their (transfer of) technology for oil exploration, production and processing has hindered the development of indigenous technology in the oil and gas industry. The implication is that Nigeria's economy is inextricably tied to foreign countries and firms, a system that is very expensive and detrimental to any homegrown industrialization agenda.

Over the years, past Nigerian administrations have introduced and implemented several policies aimed at industrializing the nation. These policies have often been imbedded in the National Development Plans (NDP) such as the first post-independence National Development Plan of 1962-1968, the Second NDP of 1970-1974, the Third NDP of 1975-1980, and the Fourth NDP of 1981-1985. The industrial policies have equally been expressed through strategic initiatives such as the Structural Adjustment Programme (SAP), the National Economic Empowerment and Development Strategy (NEEDS), the 7Point Agenda, and the Vision 20: 2020 (Commonwealth Governance, 2018).

The National Development Plans (NDPs) are principally economic and social development blueprints. In terms of industrialization, the first NDP (19621968) prescribed import substitution industrialization (ISI) to stimulate the growth of industries, to protect indigenous infant industries, to lessen dependence on foreign trade, and to reduce continuous outflow of foreign exchange. The massive investments in the energy sector during the period of the Plan exemplified by the construction of the Kanji Dam and the Ughelli Thermal Plants were aimed at providing the infrastructural nerve for the nascent industrial sector (Bevan et al., 1999). Some lapses affected the implementation of first NDP such as the incomplete feasibility studies, inadequate evaluation of projects, insufficient attention to the indigenous sector, unsatisfactory consideration for the machinery for implementing developments in the public sector, and excessive political intervention in economic decisions (Country Data, 1991).

The Second and Third Development Plans ushered in significant level of industrialization with projects such as: the cement factories at Calabar, Okpella, Nkalagu, and Shagamu; iron and steel plants at Ajaokuta and Aladja; iron and steel rolling mills at Katsina, Jos and Oshogbo; petroleum refineries at Warri and Kaduna (Teniola, 2018). Most, if not all, of these projects were built and maintained by expatriates with machinery and technology imported from other countries. Hence, local capacities, both physical and human, were not developed. Consequently, the investments and progresses that were made could not be sustained. 
The Fourth National Development Plan (1981-1985) targeted mainly to lay solid foundation for food production and manpower and infrastructure development from oil revenue. However, the plan favored Export-substitution industrialization, centered on the exportation of raw materials (especially, crude oil) and the importation of finished product such as Premium Motor Spirit (PMS) and household items. Unfortunately, the drop in global oil price, from 35.75 U.S. dollars per barrel in 1981 to 26.92 U.S. dollars per barrel in 1985, (InflationData.com, 2018) grossly affected Nigeria's foreign exchange earnings. The effects on the other sectors of the economy were enormous precipitating the introduction of austerity measures. It was perhaps the first time in the history of the nation that the risk of mono-product economy was clearly exposed, thus accentuating the need to diversify the fragile economy.

It is not out of place to say that Nigeria's National Development Plans have so far failed to fully industrialize her economy. The challenges that have hindered her industrialization include: poor physical infrastructure especially electric power supply, railway and road network; lack of investment capital; weak technological base; poor research and development culture. More worrisome and damaging, is the absence of a patriotic and competent civil service necessary for creating the enabling environment for comprehensive industrialization - the crux of this paper's thesis. In fact, these challenges have contributed to the deindustrialization of the country as some companies such as Michelin, Dunlop, Prilleri, Pan Ocean, and Unilever relocated to other countries. Some other firms either collapsed or reduced their staff strength due to the operational challenges listed above.

The introduction of the Nigeria Industrial Revolution Plan (NIRP) by the Goodluck Jonathan-led administration in 2014 signaled a renewed commitment to industrialize. NIRP is designed "to accelerate growth in those industries where Nigeria has comparative advantages such as the processing of food and agricultural products, metals and solid minerals processing, oil and gas related industries, and construction, light manufacturing and services" (UNECA, 2014). One of the policy trusts of NIRP is the 'Ease of Doing Business'. The policy, implemented by government Ministries, Departments and Agencies (MDAs), focuses on providing a business-friendly environment through strategies such as making business registration seamless and fully automated, providing visa on arrival to investors, and reducing import and export documentation requirements. Other strategies include ensuring the enforcement of contracts, providing easy access to credit, and fast-tracking the granting of permits. All these are designed to woo investors both local and foreign, and to stimulate economic growth.

\section{The role of the civil service in industrialization}

The civil service has been the 'steel frame' of Nigerian public administration system right from the colonial days. It remains the central institution through which government implements its programs designed to meet political aims and provide social services. The civil service is saddled with the responsibility of managing the daily affairs of the government and coordinating the activities of other governmental bodies towards the actualization of national development plans. The institution could therefore be described as the 'wheel' on which the State, its government and economy, run.

The role of the civil service includes to guide and to control extraministerial bodies (ad hoc and permanent) used in implementing specific aspects of government policies like the industrial policies. The civil service in some ways, exert control over 
institutions (such as the Judiciary and the legislature) which are said to be independent or corporate (Okunade, 1990). Phillips (1990) asserts that "it is from the civil service that all other institutions of the State (and business organizations) obtain various types of approvals, licenses, and permits which are crucial to their existence and operation". Thus, any form of inefficiency on the part of the civil service impacts negatively on the affairs of the dependent organizations. Government allocation of resources equally passes through the bureaucracy to all other areas of the society directly or indirectly. Consequently, all other institutions have to deal with the civil service at one point or the other in their existence and operations.

The civil service is an extension of the executive arm of government. In actual fact, the civil service provides the semblance of government. It is the main medium through which the ruling administration interfaces with the public. Thus, the institution is vital for building of public confidence in government, and for establishing mutual trust between the government and the led, and among the citizens - very crucial ingredients for national development. According to Ekeh (2009), a society with high levels of mutual trust will be able to establish large-scale industries which are essential for global competitiveness and the socioeconomic well-being of its people.

Unfortunately, the performance of the Nigerian civil service in recent times has been a source of worry to Nigerians. Babura (2003) argues that the Nigerian civil service is now highly sycophantic, inefficient, ineffective, and corrupt in virtually all its affairs. He states that there is lack of financial accountability, probity, and transparency in the operations of the civil service. According to Obasanjo (2004), the performance of the Nigerian civil service which was a source of pride to Nigerians in the 1960s, and 1970s, has deteriorated. Lawal and Oluwatoyin
(2011) are of the view that the Nigerian civil service has turned out to be an institution in which morality has reached its pits, in which undue bureaucratic practices and interminable delays, have become the hallmarks.

The poor performance of the civil service in Nigeria has led to the poor execution of the national development plans arising from the poor and corrupt implementation of the national budgets and public policies. The consequences include the inadequate quantity, quality, and access to public infrastructure such as electricity, education, healthcare, and roads, to mention a few, which are crucial for industrialization, economic growth and decent living. One other major negative implication of the poor performance of the Nigerian civil service is the unpredictability of the Nigerian polity and economy, coupled with the high cost of doing business that erode investors confidence, hence the reluctance of local and foreign investors to invest heavily in the industrial sector of the country. The cumulative effect include the high rate of unemployment, high rate of poverty, low per capita income, weak development infrastructure, and low standards of living.

It is apt, then, to argue that the industrialization of Nigeria would remain problematic due to the absence of a competent and patriotic civil service. Ekeh (2009) agrees that industrialization is inextricably connected to the ethics (and conduct) of the people running it (the civil service). $\mathrm{He}$ asserts that societies with long traditions of competent civil servants progress more than those with corrupt civil servants. For that reason, a skilled, motivated, and efficient civil service with professional ethos is a necessary condition for rapid industrialization, economic growth and social progress.

An important step toward
national development through
industrialization is to reform the civil
service to enhance its capacity to deliver


services required for economy growth. The introduction of the Service Compact (Servicom) Charter was propelled by this desire. The Service compact charter was instituted because of the conviction that Nigeria can only realize its full potentials if citizens (and visitors) receive prompt and efficient services from the State (Oladele, 2014). The government of Nigeria under the leadership of Olusegun Obasanjo in the Fourth Republic realized that the shortcomings of the civil service such as the high level of bribery and corruption, indiscipline and dereliction of duty by public servants, and the nonchalant attitude of civil servants to work were capable of derailing government's economic plans, especially her industrialization policy. Hence, the government responded by initiating the Service Compact (Servicom) Charter.

\section{Theoretical foundation of Servicom}

The Servicom Charter is anchored on the New Public Management (NPM) Theory. NPM theory proposes a management culture that emphasizes the centrality of the citizens or customers, as well as accountability for results (Economic Commission for Africa, 2003). It advocates radical organization reinvention, restructuring to focus on core competence, and reengineering of work process. NPM favors realignment by introducing activity-based costing and responsibility budgeting, and the re-conceptualization of the public sector bureaucracies (Jones and Thompson, 1999). Hood (1991) identified the principles of NPM as, accountability and efficiency, reduction of public sector expenditure and improvement in decision making, competition in the public sector through decentralization, and emphasis on result and not procedure. Shah (2006) affirmed that the focus on result-based accountability and client-orientation encourages the civil service to innovate.
A number of criticisms have been leveled against the tenets of New Public Management theory. One of the criticisms relate to the paradox of centralization through decentralization. Maor (1999) argued that NPM actually leads to centralized decision-making rather than promoting decentralization in public organizations. In his view, giving public managers too much authority to manage programs may result in absolute concentration of decision-making. Minogue (2001) and Hughes (2003) reasoned that increased managerial autonomy creates more opportunities for public managers to become corrupt or exhibit unethical behaviors particularly as it concerns contracting. Overall, critics have highlighted the difficulties in applying private sector management practices in the public sector organizations. For instance, Singh (2003) stressed the weakness of NPM by asserting that the political context of the public sector makes it difficult to comprehensively apply private sector management practices. He argued that the goals of public organizations are shaped by the desires of the political leadership rather than by profit orientation.

The criticisms have prompted scholars, such as Osborne (2006) and Denhardt and Denhardt (2011), to propose new public administration theories/models like the "New Public Service", "New Public Governance", and the "Post-New Public Management." They argue that these models will create true decentralization by enhancing the role of the citizens in the decision making processes in public administration. The theories/models share similar focus with New Public Management as they all place the interest of the citizens or customers at the center of service delivery. This author therefore holds that, the new public management theory is appropriate for reviewing the role of the civil service in the industrialization of Nigeria because of its emphasis on citizen- and customer-centered service 
delivery by a competent and patriotic bureaucracy - a necessary condition for creating a business- and investorfriendly environment for industrialization, economic growth, and national development.

\section{Conclusion}

The central argument in this paper is that, no matter the strategy articulated in an industrial policy, it is extremely pertinent to have a competent civil service to patriotically implement it. The services and regulatory inputs of the civil service are part of the essential factors that catapult a nation to industrialized status. The current Nigeria Industrial Revolution Plan and its component Ease of Doing Business Policy can fast-track the industrialization and economic development of the country if expertly and patriotically implemented by the nation's civil servants. The Servicom initiative is put forward as the right policy to reform and position the civil service for these very important tasks. Several studies have pointed to the positive effect of servicom on public employees' performance and on public service delivery in Nigeria. For instance, Kirfiret al. (2013) found that the objectives and delivery mechanisms of Servicom are appropriate remedies for poor service delivery in the Nigerian public sector. Onyema (2017) suggests that the implementation of the Servicom charter has had positive effect on the work performance of federal civil servants. This paper therefore recommends that the Servicom charter be sustained and incorporated into the overall industrialization strategy of the Federal Government of Nigeria.

\section{Conflicts of interest}

Author declares that they have no conflict of interests.

\section{References}

Abercrombie, N.; Hill, S.; Turner, B. S. The Penguin Dictionary of Sociology. 4. ed. London: Penguin Group, 2000.

Babura, A. S. M. Leading public service innovation: The case of the Nigeria Civil Service and Federal Civil Service Commission. Abuja: Federal Civil Service Commission, 2003.

Bevan, D.; Collier, P.; Gunning, J. W. The political economy of poverty, equity and growth: Nigeria and Indonesia. Washington, DC: World Bank and Oxford, Oxford University Press, 1999.

Commonwealth Governance. National Development Plan of Nigeria. 2018. Available from: <http://www.commomwealthgover nance.org/countries/africa/nigeria/nationaldevelopment-plan/>. Accessed on: Apr. 23, 2018.

Country Data. Nigeria: Planning. 1991. Available from: <http://www.countrydata.com/cgi-bin/query/r-9401.html>.

Accessed on: Apr. 23, 2018.

Denhardt, J. V.; Denhardt, R. B. The new public service: Serving, not steering. 3. ed. Armonk, NY: M. E. Sharpe, 2011.

Ekeh, L. U. Industrialization and national prosperity: Lessons for the developing countries. London: LUZEK Publishers, 2009.

Hood, C. A public management of all season? Public Administration, v. 69, no. 1, p. 3-19, 1991. https://doi.org/10.1111/j.14679299.1991.tb00779.x

Hughes, O. E. Public management and administration. New York: Palgrave Macmillan, 2003.

InflationData.com. Historical Crude Oil Prices (Table): Oil Prices 1946-Present. 2018. Available from: <https://inflationdata.com/ inflation/inflation_Rate/Historial_Oil_Prices_ Table.asp>. Accessed on: Apr. 23, 2018.

Johnston, W. Export-led growth strategies through History. 2016. Available from: <https://www.investopedia.com/articles/in vesting/011416/exportled-growthstrategies-through-history.asp>. Accessed on: Apr. 23, 2018.

Jones, R.; Thompson, F. Public management: Institutional renewal for the 21st Century. Stamford, CT: Elsevier, 1999. 
Kirfi, M. M. W.; Balarabe, A.; Shantali, M. J. Service compact (Servicom) and Service delivery in Nigerian public teaching hospitals: A study of Usman Danfodiyo University Teaching Hospital (UDUTH) Sokoto. Journal of International Academic Research for Multidisciplinary, v. 1, no. 6, p. 18-35, 2013. Available from: <http://jiarm.com/Jul/paper3832.pdf>.

Accessed on: Apr. 23, 2018.

Lawal, T.; Oluwatoyin, A. The civil service and sustainable development in Nigeria. Journal of Sustainable Development in Africa, v. 13, no. 4, p. 385-393, 2011. Available from: <http://www.jsd-africa.com/Jsda/Vol13

No4_Summer2011_B/PDF/The Civil Service and Sustainable Development in Nigeria1.pdf>. Accessed on: Apr. 23, 2018.

Maor, M. The paradox of managerialism. Public Administration Review, v. 59, p. 518, 1999.

Marshall, G. Oxford Dictionary of Sociology. 2. ed. New York: Oxford University Press, 1998.

Minogue, M. The internationalization of new public management. In: McCourt, W.; Minogue, M. (Eds.). The internationalization of public management: Reinventing the Third World State. Northampton, MA: Edward Elgar Publishing, 2001. p. 1-19.

NNPC - Nigeria National Petroleum Corporation. History of the Nigerian Petroleum Industry. 2016. Available from: <http://www.nnpcgroup.com/NNPCBusines s/Businessinformation/OilGasinNigeria/Ind ustryHistory.aspx>. Accessed on: Apr. 23, 2018.

Obasanjo, 0. The imperative of civil service reform. In: Adegoroye, G. (Ed.). Nigeria public service reform: The visions and challenges. Abuja: Bureau of Public Service Reforms, 2004.

Okunade, B. The Nigerian civil service: The journey so far. In: Ujo, A. A. (Ed.). Three decades of the Nigerian civil service. Jos: Nigeria Political Science Association, 1990. p. 20-22.
Oladele, A. Civil service reform of the Federal Government. 2014. Available from: <https://www.3psmars.org/civil-servicereform-federal-government/>. Accessed on: Apr. 23, 2018.

Onyema, C. Effects of public service renewal programme on employee performance in the federal civil service, Imo State, Nigeria. Awka: Nnamdi Azikiwe University, 2017. (Doctoral dissertation).

Osborne, S. P. The new public governance? Public Management Review, v. 8, no. 3, p. 377-388, 2006.

Phillips, D. The 1988 Nigeria civil service reforms and their post-1992 prospects. Ibadan: Nigerian Institute Social and Economic Research 1990. (NISER Occasional Paper, 1).

Shah, A. Corruption and decentralized public governance. World Bank Policy Research Working Paper, no. 3824, p. 1-30, 2006.

Singh, A. Questioning the new public management. Public Administration Review, v. 63, no. 1, p. 116-119, 2003.

Teniola, E. Our new national development plan. Vanguard Media, Nigeria, 2018. Available from: <https://www.vangua rdngr.com/2018/03/our-new-nationaldevelopment-plan/>. Accessed on: Apr. 23, 2018.

UNECA - United Nations Economic Commission for Africa. Dynamic Industrial Policy in Africa: Nigeria's Industrial Revolution Plan Unveiled. 2014. (Economic Report on Africa). Available from: <https://www.uneca.org/sites/default/files/ uploaded-documents/COM/com2014/ era_2014_feature_story_nig_eng.pdf > .

Accessed on: Apr. 23, 2018.

UNECA - United Nations Economic Commission for Africa. Public sector management reforms Africa: Lessons learned. 2003. (ECA/DPMD/PSM/TP/03/1). Available from: <http://www.uneca.org>. Accessed on: Apr. 23, 2018. 